\title{
Evaluating the Natrium lodide Symporter Expressions in Thyroid Tumors
}

\author{
Aisyah Elliyanti $^{1,2 * \mathbb{D}}$, Rony Rustam ${ }^{3}$, Tofrizal Tofrizal ${ }^{4}$, Yenita Yenita ${ }^{4}$, Yayi D. Billianti Susanto ${ }^{5}$ \\ ${ }^{1}$ Department of Medical Physics, Faculty of Medicine, Universitas Andalas, Padang, Indonesia; ${ }^{2}$ Division of Nuclear Medicine, \\ Department of Radiology, Dr. M.Djamil Hospital, Padang, Indonesia; ${ }^{3}$ Department of Surgery, Faculty of Medicine, Universitas \\ Andalas, Padang, Indonesia; ${ }^{4}$ Department of Pathology Anatomy, Faculty of Medicine, Universitas Andalas, Padang, Indonesia; \\ ${ }^{5}$ Department of Pathology Anatomy, Faculty of Medicine, Universitas Indonesia, Jakarta, Indonesia
}

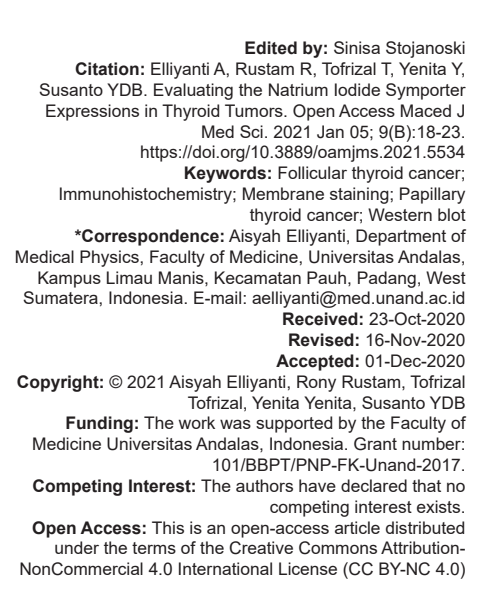

Introduction

One of the most common endocrine neoplasms is thyroid cancer [1]. In most countries, thyroid cancer incidence rate has increased, and it does have a steady mortality rate [2], [3], [4], [5]. Thyroid cancer is the eleventh rank cause of deaths from cancer [6]. This cancer incidence is rapidly increasing in developed countries compared to developing countries in females and males [7]. The rising of advanced detection technologies and changing lifestyles in developed countries can be the reasons.

The follicular and parafollicular thyroid cells are two primary parenchymal cells of thyroid cancer origin. These can rise to be well-differentiated thyroid cancer (DTC) such as papillary and follicular types. Well-differentiated is the majority incidence of thyroid cancer, papillary (80\%) and follicular (10\%). Then, it is followed by poorly DTC, medullary (5-9\%), and anaplastic (2\%) [8]. DTC is associated with a good prognosis.

\begin{abstract} cancer cells' plasma membrane leads to radioiodine-refractory disease.
\end{abstract}

MATERIALS AND METHODS: The samples were thyroid tissues of patients who underwent surgery for a thyroid tumor. The tissues were processed for NIS protein expressions by immunohistochemistry (IHC) and Western blot pamples were used as positive controls. The samples were incubated without the primary antibody, and they were used as negative controls for IHC examination. Na+/K+ ATPase was a plasma membrane

RESULTS: Twenty-nine samples were assessed for NIS protein. All of them showed the expression in the cytoplasm with intensity $1+$ to $3+$ with Allred score 3-8. Fourteen out of 29 cases $(48.2 \%)$ showed NIS cytoplasm staining Membrane staining was found in 2 samples of PTC (6.9\%). Six samples (adenoma 1 sample, PTC 5 samples)

CONCLUSION: NIS expression in thyroid cancer mostly expresses in the cytoplasm instead of the membrane. NIS the main reason for the lack of response of radioiodine in some differentiated thyroid cancers.
Radioiodine $\left({ }^{131} \mathrm{I}\right)$ has been used for adjuvant therapy to manage well-DTC for more than 60 years. Beta $(\beta)$-emitting of ${ }^{131} \mathrm{I}$ is used to destroy remaining thyroid cells post-thyroidectomy included metastases [9], [10], [11], [12], [13]. It is relatively un-expensive and widely available. It increases up to $80 \%$ of the 10 -year survival rate and decreases the death number compared to patients who had not received ${ }^{131}$ I (3\%: 12\%) [14], [15]. On the other hand, some thyroid cancers and metastases showed low uptake of ${ }^{131}$ I compare to healthy thyroid tissues [16]. One-third of advanced DTC metastases show low avidity to iodine [8], [17], [18], [19]. Losing the ability to concentrate iodine can occur during the progression of the disease.

lodine is transporting into follicular thyroid cells against the electrochemical gradient. In a normal condition, a gradient between a thyroid cell and an extracellular is 100:1 [20]. Natrium iodide symporter(NIS) is used for iodine to cross the cell membrane. It resides in the thyroid in the basolateral membrane of epithelial cells and transports two cations of sodium $(\mathrm{Na}+)$ and one anion of iodide (I-) into the cells. This process is facilitated by an enzyme $\mathrm{Na}+\mathrm{K}+$ ATPase [21], [22], [23]. 
Decreased NIS expression levels or diminished NIS targeting to thyroid cancer cells' plasma membrane lead to radioiodine-refractory disease. The main reason for impaired of ${ }^{131} \mathrm{I}$ uptake is defective of NIS expression [15], [17], [23], [24]. This study aims to analyze the NIS expression in thyroid tumors.

\section{Materials and Methods}

The samples were thyroid tissues of patients who underwent surgery for thyroid diseases during June to September 2017. Twenty-nine samples were classified as thyroid diseases, according to the World Health Organization recommendation by pathologists using hematoxylin and eosin staining [25]. The tissues were processed at the Pathology Anatomy Department of Faculty of Medicine Universitas Andalas. If the samples were not possible to process quickly, they were stored at $-4^{\circ} \mathrm{C}$. NIS protein expressions were analyzed by immunohistochemistry (IHC) and Western blot (WB) studies. Ethical approval was obtained from the Ethics Committee of Medical Faculty of Universitas Andalas \# 357/KEP/FK/2017.

\section{IHC}

Paraffin blocks cut into $4 \mathrm{~mm}$ slices and placed on microscope slides. These were then deparaffinized, rehydrated, and incubated with sodium iodide symporter antibody (FP5A, Thermo Scientific) at a 1:200 dilution for $60 \mathrm{~min}$ at room temperature. The slides were rinsed in phosphate-buffered saline and incubated in a Starr Trek Universal HRP Detection Kit for 15 min. Then, they were incubated using a diaminobenzidine detection kit. Graves' disease samples were used as positive controls. The samples were incubated without the primary antibody, and they were used as negative controls.

All slides were evaluated by light microscopy. The level of NIS expression was analyzed by three pathologists. Samples were examined in tumor areas. The membrane expression was scored using a scale of 0 to $3+$ according to HER2/neu staining criteria. A score of 0 if no stain at the membrane, score $1+$ if the membrane was staining more than $10 \%$ cell population. A score of 0 or 1 was considered negative. Score $2+$, if moderate staining $>10 \%$ cell population and $3+$ strong circumferential stainings $>10 \%$ cell population. Score 2 and 3 were considered a positive result [26]. Cytoplasmic staining refers to the Allred technique with criteria; 0 if no staining, $1+$ weak staining at the majority of the field of view, 2+ moderate, and 3+ strong staining. Intensity value was reported as staining intensity majority in all fields of view. The proportion of positive cells is the percentage of all cell positive stain regardless of the level of intensity. It was reported in percentage. Allred score was summation between proportion and intensity with score 0-8 [27].

\section{WB}

Membrane protein was isolated from thyroid samples. The membrane protein $(100 \mu \mathrm{g})$ was added to the sample buffer (NuPAGE LDS sample buffer $\times 4$, NuPAGE reducing Agent $\times 10$, deionized water, Thermo Scientific) and heated for $10 \mathrm{~min}$ at $70^{\circ} \mathrm{C}$. The protein was separated by SDS/PAGE (NuPAGE MOPS SDS buffer kit, Thermo Scientific), then transferred to a PVDF membrane (iBlot2 transfer stacks, Thermo Scientific) for $1.5 \mathrm{~h}$. The blot stained to check protein on the membrane (SeeBlue Plus2, Thermo Scientific). Then, a blocking buffer was added to the membrane for $30 \mathrm{~min}$ to block nonspecific binding. It followed by incubating the membrane in monoclonal antibody sodium iodide symporter (FP5A, Thermo Scientific) $1: 1000$ at $4^{\circ} \mathrm{C}$ overnight. After three piles of washing, the membrane was incubated with secondary antibody 1:200 (goat anti-mouse IgG $(\mathrm{H}+\mathrm{L})$, Peroxidase Conjugate, Thermo Scientific) for $2 \mathrm{~h}$ at room temperature. Next, the membrane was covered with Horseradish peroxidase (1-step ultra tetramethylbenzidine-blotting solution). PVDF membrane was stripped and re-probed with $\mathrm{Na}+\mathrm{K}+$ ATPase alpha antibody (M7-PB-E9, Thermo Scientific) as plasma membrane protein markers.

\section{Statistical analysis}

Experiments were performed in duplicate. Data and results are presented as the means \pm standard deviations (SD). Kruskal-Wallis test and MannWhitney were used for data analysis, and $p<0.05$ was considered statistically significant.

\section{Results}

Twenty-nine samples were analyzed from patients who underwent thyroidectomy. Two males and 27 females, and the mean age were $50.5 \pm 10.5$ years old. Papillary thyroid cancer (PTC) was 18 samples $(62.1 \%)$, FTC three samples $(10.3 \%)$, adenomas seven samples $(24.2 \%)$, and Cyst one sample $(3.4 \%)$ shown in Table 1.

\section{IHC staining in thyroid tissues}

Twenty-nine samples were assessed for NIS protein. All of them showed the expression in the cytoplasm with intensity $1+$ to $3+$ with Allred score 
Table 1: Patients characteristics of thyroid tissues samples

\begin{tabular}{|c|c|c|c|c|c|c|c|c|c|c|}
\hline S. No & Age & Gender & Sample & Histopathology & ATP $\sim 80 \mathrm{kDa}$ & $\mathrm{NIS} \sim 80 \mathrm{kDa}$ & Membrane staining & Intensity & Cytoplasm proportion & Allred score \\
\hline 1 & 45 & M & $1 \mathrm{P}$ & Adenoma & + & + & - & + & 90 & 6 \\
\hline 2 & 33 & $\mathrm{~F}$ & $4 \mathrm{P}$ & Cyst & + & - & - & + & 90 & 6 \\
\hline 3 & 47 & $\mathrm{~F}$ & $5 P$ & PTC & + & + & - & + & 80 & 6 \\
\hline 4 & 35 & M & $6 \mathrm{P}$ & PTC & + & - & - & ++ & 80 & 7 \\
\hline 5 & 42 & $\mathrm{~F}$ & $7 \mathrm{P}$ & PTC & + & $62 \mathrm{kDA}$ & - & ++ & 80 & 7 \\
\hline 6 & 52 & $\mathrm{~F}$ & $8 \mathrm{P}$ & PTC & + & + & - & + & 70 & 6 \\
\hline 7 & 46 & $\mathrm{~F}$ & 9P & Adenoma & + & - & - & + & 80 & 6 \\
\hline 8 & 36 & $\mathrm{~F}$ & $10 \mathrm{P}$ & PTC & + & + & - & ++ & 70 & 7 \\
\hline 9 & 62 & $\mathrm{~F}$ & $11 \mathrm{P}$ & PTC & + & - & - & ++ & 70 & 7 \\
\hline 10 & 36 & $\mathrm{~F}$ & $12 \mathrm{P}$ & Adenoma & + & + & + & ++ & 80 & 7 \\
\hline 11 & 49 & $\mathrm{~F}$ & $13 P$ & Adenoma & + & $49 \mathrm{kDa}$ & - & + & 50 & 5 \\
\hline 12 & 58 & $\mathrm{~F}$ & $14 \mathrm{P}$ & PTC & + & + & + & ++ & 90 & 7 \\
\hline 13 & 48 & $\mathrm{~F}$ & $15 \mathrm{P}$ & FTC & + & + & - & ++ & 60 & 6 \\
\hline 14 & 52 & $\mathrm{~F}$ & $16 \mathrm{P}$ & PTC & + & + & - & + & 70 & 6 \\
\hline 15 & 74 & $\mathrm{~F}$ & $17 \mathrm{P}$ & PTC & + & $49 \mathrm{kDa}$ & - & + & 30 & 4 \\
\hline 16 & 75 & $\mathrm{~F}$ & $18 \mathrm{P}$ & FTC & + & + & - & ++ & 80 & 7 \\
\hline 17 & 52 & $\mathrm{~F}$ & $19 \mathrm{P}$ & PTC & + & + & - & + & 30 & 4 \\
\hline 18 & 57 & $\mathrm{~F}$ & $20 \mathrm{P}$ & Adenoma & NA & NA & - & + & 20 & 3 \\
\hline 19 & 45 & $\mathrm{~F}$ & $21 \mathrm{P}$ & PTC & + & $62 \mathrm{kDa}$ & ++ & + & 60 & 5 \\
\hline 20 & 55 & $\mathrm{~F}$ & $22 \mathrm{P}$ & PTC & + & - & + & + & 50 & 5 \\
\hline 21 & 36 & $\mathrm{~F}$ & $23 \mathrm{P}$ & PTC & + & + & + & ++ & 50 & 6 \\
\hline 22 & 54 & $\mathrm{~F}$ & $25 \mathrm{P}$ & PTC & + & $49 \mathrm{kDa}$ & + & ++ & 60 & 6 \\
\hline 23 & 52 & $\mathrm{~F}$ & $26 \mathrm{P}$ & Adenoma & NA & NA & - & + & 30 & 4 \\
\hline 24 & 47 & $\mathrm{~F}$ & $27 \mathrm{P}$ & PTC & NA & NA & - & +++ & 50 & 7 \\
\hline 25 & 64 & $\mathrm{~F}$ & $28 \mathrm{P}$ & PTC & + & + & ++ & ++ & 80 & 7 \\
\hline 26 & 51 & $\mathrm{~F}$ & $29 \mathrm{P}$ & PTC & + & + & - & + & 60 & 5 \\
\hline 27 & 63 & $\mathrm{~F}$ & $30 P$ & FTC & + & + & - & ++ & 80 & 7 \\
\hline 28 & 52 & $\mathrm{~F}$ & $31 \mathrm{P}$ & PTC & + & - & + & +++ & 90 & 8 \\
\hline 29 & 47 & $\mathrm{~F}$ & $32 \mathrm{P}$ & Adenoma & + & - & - & + & 80 & 6 \\
\hline
\end{tabular}

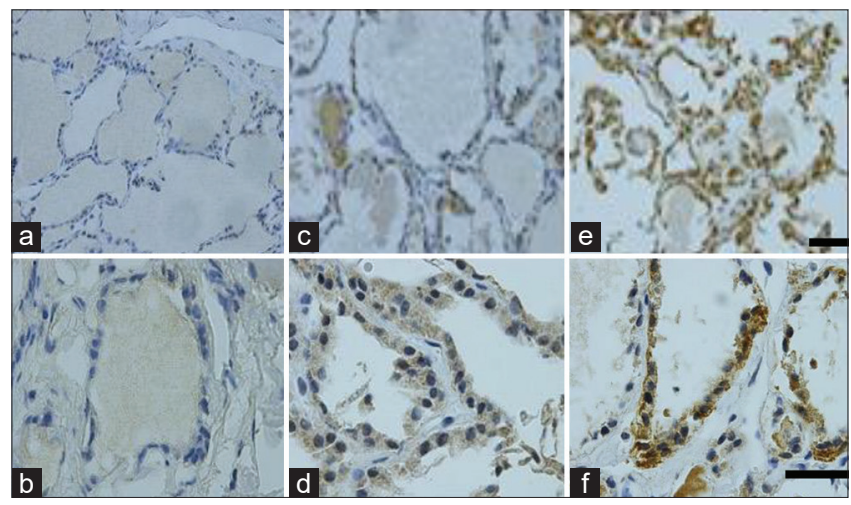

Figure 1: Cytoplasmic Natrium iodide symporter expression at follicle cell of adenoma goiter show a weak intensity $(+)(a$ and $b)$, moderate $(++)(c$ and d), and strong (+++) (e and f). No staining at stromal and vascular. Most of the samples show NIS cytoplasmic intensity weak to a moderate level. Bar $100 \mu \mathrm{m}$

$3-8$. Fourteen out of 29 cases $(48.2 \%)$ showed NIS cytoplasm staining intensity $\geq 2+$, with Allred score 6-8 (mean 6.85 \pm 0.53 ), consist of ten PTC, three FTC and one adenoma (Table 1, and Figure 1a-f, 2a-f).

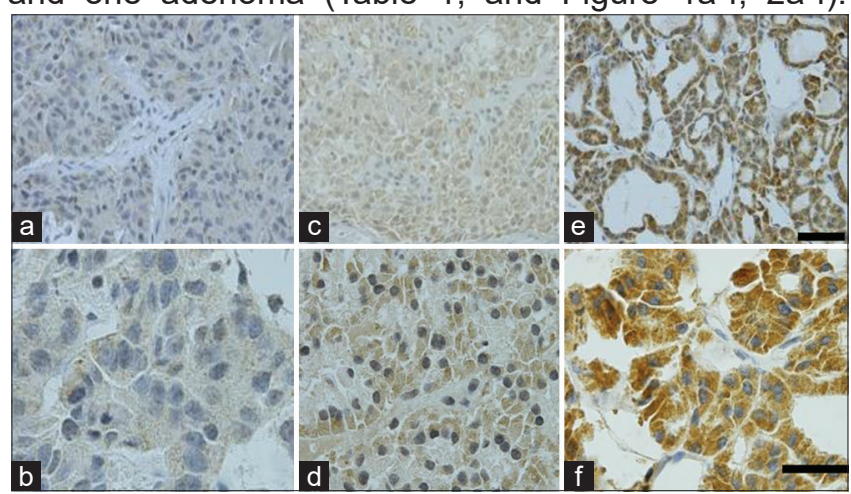

Figure 2: Cytoplasmic pattern of staining in thyroid cancer; weak $(+)(a$ and b), moderate (++) (c and d), and strong (+++) (e and f). There is no staining at the stromal cell and vascular. The majority of samples demonstrate Natrium iodide symporter expression intensity weak to moderate. Bar $100 \mu \mathrm{m}$
Fifteen samples $(51.7 \%)$ the cytoplasm staining 1+, with Allred score 3-6 (mean 5.13 \pm 0.99 ), consist of eight PTC, six adenomas, one cyst. The protein expression was not significantly different $(p$ $=0.77$ ) between intensity of staining and WB results (Figure 3). Membrane staining was found in two (6.9\%) samples of PTC samples (Figure 4a-c). Six samples (adenoma one sample, PTC five samples) showed NIS expression at membrane very weak $(1+)$; they were considered as negative.

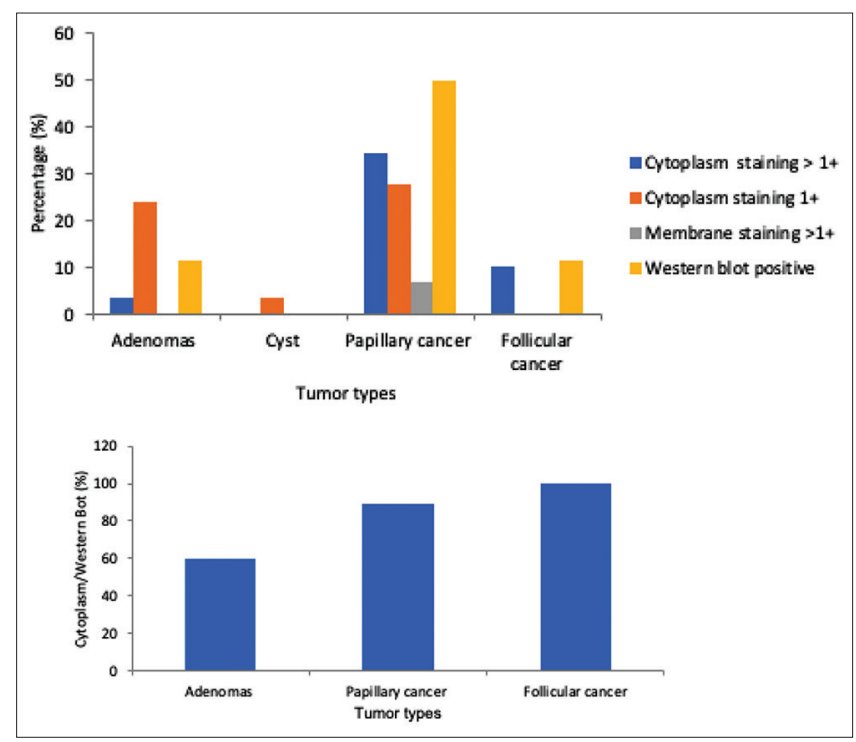

Figure 3: Natrium iodide symporter protein expressions based on thyroid disease types. The expression mostly in the cytoplasm in all types. Fourteen PTC samples expressed NIS in cytoplasm varying $1+$ to $2+$ with bands $\sim 80, \sim 62$, and $\sim 49 \mathrm{kDa}$. Membrane positive staining is found in $6.9 \%$ samples of PTC, which correlated with molecule weight $\sim 80 \mathrm{kDa}$. FTC samples expressed NIS protein in the cytoplasm with intensity $>1+$ have a band $\sim 80 \mathrm{kDa}$ (above). Protein expression was not significantly different between IHC and WB. Percentage of NIS protein expression in cytoplasm expression with WB results in adenomas, PTC, and FTC, 60\%,89\%, 100\%, respectively (below) 


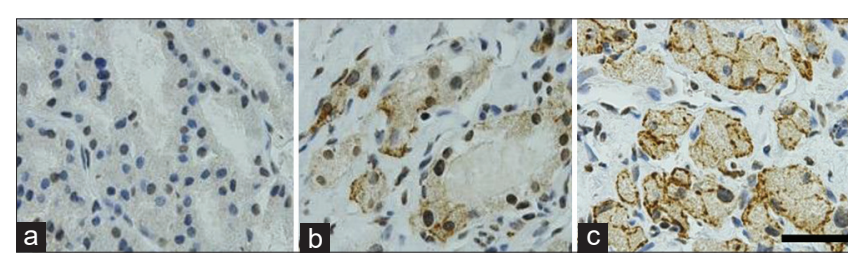

Figure 4: Pattern of the staining at the membrane. Negative Natrium iodide symporter expression (a), weak membrane expression and intensity (1+) (b), moderate staining (2+) (c). No stain at stromal cell and vascular. Bar $100 \mu \mathrm{m}$

\section{WB analysis in thyroid tissues}

NIS protein was analyzed in 26 of 29 thyroid samples because only the large tumor size could proceed with WB analysis. NIS protein is detected with molecule weight $\sim 80, \sim 62$, and $\sim 49 \mathrm{kDa}$. The samples consist of 17 PTC, three FTC, five adenomas, and one thyroid cyst (Table 1). Nineteen samples expressed NIS protein, three adenoma samples, and 13 PTC three FTC samples. They migrated with a molecular weight of $\sim 80 \mathrm{kDa}$ in 14 samples and four samples with a molecular weight of $\sim 62 \mathrm{kDa}$. Two samples expressed NIS protein at the membrane, migrate with a molecular weight of $\sim 80 \mathrm{kDa}$ and $\sim 62 \mathrm{kDa}$ (Figure 5). There was no significantly different the protein expression between WB and IHC results, with $\mathrm{p}=0.25$.

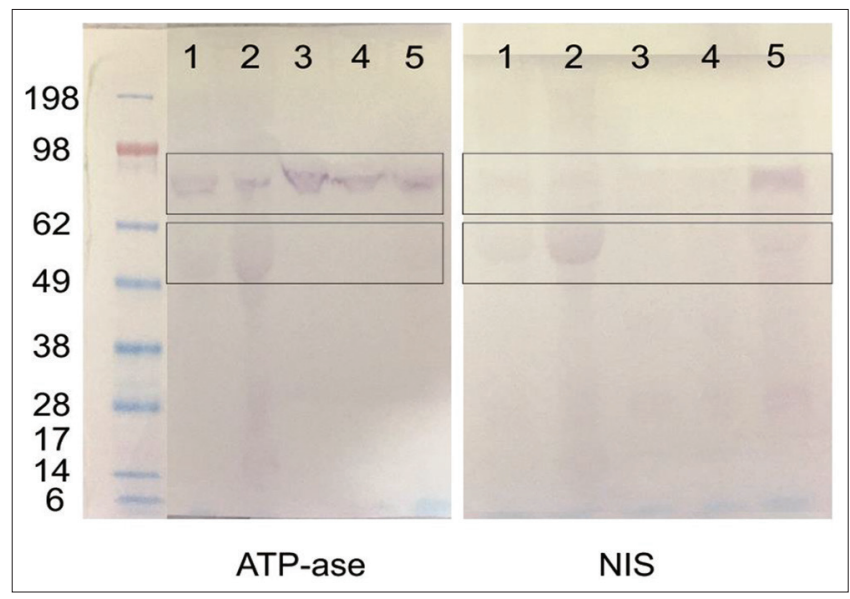

Figure 5: Natrium iodide symporter expression blotting result in thyroid tissues; the major band is detected with molecular weight $\sim 80$ $\mathrm{kDa}$ and several minor bands $\sim 62$, and $\sim 49 \mathrm{kDa}$

\section{Discussion}

The classification samples were based on the histopathology examination. Seven of the samples were adenomas. All of them showed NIS protein expression in the cytoplasm in vary intensities $(1+$ to $3+)$. However, only one showed membrane expression 1+ with intensity in cytoplasm 2+, Allred scores 7, and the protein band $\sim 80 \mathrm{kDa}$. The condition was also reported by other studies [28], [29], [30], [31]. The different staining intensity likely related to varying NIS protein expression in different thyroid sample types [31]. NIS protein is expressed in cytoplasm in all PTC and FTC as shown in Table 1.

NIS protein major band with molecular weight -80 kDa, and several minor bands with molecular weight approximately $62 \mathrm{kDa}$ and $49 \mathrm{kDa}$. This report in line with other studies [28], [29], [30], [31], [32]. The minor bands can be a degradation fragment. However, further studies are needed to elaborate on this issue. NIS protein-membrane was expressed in $6.9 \%$ samples of PTC, one with a molecular weight of $\sim 80 \mathrm{kDa}$ and another $\sim 62 \mathrm{kDa}$.

NIS expression levels are generally reduced in malignant thyroid tissue relative to normal tissue [16], [33]. It may result from multiple mechanisms elicited by several signaling pathways involved in thyroid tumorigenesis included genetic alternations [31], [34], [35]. Understanding the molecular background for thyroid cancer can lead to developing agents blocking the inappropriately activated pathway in cancer cells as a novel treatment strategy. Furthermore, NIS expression appears to be modulated by post-transcriptional events. A study reported that NIS is differentially expressed according to the tumor's genetic background [31]. However, the molecular mechanisms responsible for the downregulation of NIS in thyroid tumors remain poorly understood. On the other hand, NIS expression in the thyroid depends on inducing thyroid stimulation hormone (TSH), and low TSH levels affect ${ }^{131}$ I uptake. It is known that TSH stimulates radioiodine uptake by DTC cells [16], [18]. It may be another factor that leads to reduced NIS expression and iodide-concentrating capacity in the thyroid cells.

${ }^{131} \mathrm{I}$ is generally effective for thyroid cancer. Two-thirds of thyroid cancer patients showed ${ }^{131}$ I uptake, and one-third of thyroid cancer is reported low or negative uptake of ${ }^{131} \mathrm{I}$, which has turned out to be ineffective [8]. Higher NIS expression is associated with higher uptake of ${ }^{131} \mathrm{I}$ by thyroid cell [18], [34]. Thyroid cells that do not respond to radioiodine can be lost NIS expression [15], [17], [23], [24]. The availability of specific polyclonal and monoclonal anti-hNIS antibodies has allowed the investigation of NIS protein expression levels in various thyroid tissues. Around $70-80 \%$ of thyroid cancers that express NIS are still well-differentiated regardless of their stage [30], [36], [37]. It seems that cell differentiation in thyroid cancer may associate with the NIS expression and radioiodine accumulation [35], [36]. Undifferentiated thyroid cancer cells unable to concentrate ${ }^{131} \mathrm{I}$. It was assumed due to the absence of or low NIS expression [30], [38]. Impaired functional NIS can be the main reason for less response to a thyroid cancer cell to radioiodine. Some studies reported that NIS expresses mostly intracellular than at the plasma membrane [13], [18], [28], [29], [30], [31], [39].

Astudy reported that ${ }^{131}$ I therapy's effectiveness does not solely depend on the amount of ${ }^{131} \mathrm{I}$, in which transport is facilitated by NIS [39]. $A^{131}$ I reduced breast 
cancer cells (MCF7) proliferation in vitro, eventhough the cells did not express NIS protein [40], [41]. The condition can happen because the cell has its mechanism to the response of radiation [12], [13], [20], [42]. Another study reported that NIS expression might help characterize patients' risk with inadequate therapy response [31], [43]. Further research related to biological tumor behavior to radioiodine exposure included retrospective studies in large number series, is still needed.

\section{Conclusion}

NIS expression in thyroid cancer mostly expresses in the cytoplasm than the membrane. It can be one of the reasons for the ineffective radioiodine in some DTCs. To achieve an appropriate ${ }^{131}$ I toxic effect without harming normal cells, translocation of NIS to the membrane may be one strategy that needs to consider tumor biology behavior. However, advanced studies of the NIS role in radioiodine transport are still needed.

\section{Ethical Approval}

All procedures performed in studies involving human participants were in accordance with the ethical standards of the institutional and/or national research committee and with the 1964 Helsinki declaration and its later amendments or comparable ethical standards.

\section{Authors' Contributions}

Aisyah Elliyanti: Performed the experiments, analyzed data, and drafted and edited this manuscript. Rony Rustam: Contributed in preparation methods and edit the manuscript. Tofrizal Tofrizal: Contributed analyzed data and writing the manuscript. Yenita Yenita: Analyzed data and edit the manuscript. Yayi D. Billianti Susanto: Analyzed data and edit the manuscript.

\section{References}

1. Soheylizad M, Khazaei S, Jenabi E, Delpisheh A, Veisani Y The relationship between human development index and its components with thyroid cancer incidence and mortality: Using the decomposition approach. Int $\mathrm{J}$ Endocrinol Metab. 2018;16(4):e65078.

\section{PMid:30464773}

2. La Vecchia C, Malvezzi M, Bosetti C, Garavello W, Bertuccio P, Levi F, et al. Thyroid cancer mortality and incidence: A global overview. Int J Cancer. 2015;136(9):2187-95

PMid:25284703

3. Siegel RL, Miller KD, Jemal A. Cancer statistics, 2015. CA Cancer J Clin. 2015;65(1):5-29.I

PMid:25559415

4. Yu F, Ma J, Huo K, Li P. Association between breast cancer and thyroid cancer: A descriptive study. Transl Cancer Res. 2017;6:393-40.

5. Roman BR, Morris LG, Davies L. The thyroid cancer epidemic, 2017 perspective. Curr Opinion Endocrinol Diabetes Obes. 2017;24:332-6.

6. Bray F, Ferlay J, Soerjomataram I, Siegel RL, Torre LA Jemal A. Global cancer statistics 2018: GLOBOCAN estimates of incidence and mortality worldwide for 36 cancers in 185 countries. CA Cancer J Clin. 2018;68(6):394-424. PMid:30207593

7. Olson E, Wintheiser G, Wolfe KM, Droessler J, Silberstein PT. Epidemiology of thyroid cancer: A review of the national cancer database, 2000-2013. Cureus. 2019;11:e4127. PMid:31049276

8. Tumino D, Frasca F, Newbold K. Updates on the management of advanced, metastatic, and radioiodine refractory differentiated thyroid cancer. Front Endocrinol (Lausanne). 2017;8:312. PMid:29209273

9. Dohan O, De La Vieja, Paroder V, Riedel C, Artini M, Reed M, et al. The sodium/iodide symporter (NIS): Characterization, regulation and medical significance. Endocr Rev. 2003;24(1):48-77. PMid: 12588808

10. Haymart MR, Banerjee M, Stewart AK, Koenig RJ, Birkmeyer JD, Griggs JJ. Use of radioactive iodine for thyroid cancer. JAMA. 2011;306(7):721-8

PMid:21846853

11. Lakshmanan A, Scarberry D, Shen DH, Jhiang SM. Modulation of sodium iodide symporter in thyroid cancer. Horm Cancer. 2014;5(6):363-73.

PMid:25234361

12. Bonnema SJ, Hegedüs L. Radioiodine therapy in benign thyroid diseases: Effects, side effects, and factors affecting therapeutic outcome. Endocr Rev 2012;33:920-80 PMid:22961916

13. Wyszomirska A. lodine-131 for therapy of thyroid diseases. Physical and biological basis. Nucl Med Rev Cent East Eur. 2012;15(2):120-3. PMid:22936505

14. Hingorani M, Spitzweg C, Vassaux G, Newbold K, Melcher A Pandha $\mathrm{H}$, et al. The biology of the sodium iodide symporter and its potential for targeted gene delivery. Curr Cancer Drug Targets. 2010;10(2):242-67.

PMid:20201784

15. Choi YW, Kim HJ, Kim YH, Kim YH, Park SH, Chwae YJ, Lee J, et al. B-RafV600E inhibits sodium iodide symporter expression via regulation of DNA methyltransferase 1. Exp Mol Med. 2014;46(11):e120.

16. Slonimsky E, Tulchinsky M. Radiotheragnostics paradigm for radioactive iodine (lodide) management of differentiated thyroid cancer. Curr Pharm. 2020;26(31):3812-27. PMid:32503402

17. Faria $\mathrm{M}$, Domingues $\mathrm{R}$, Paixão $\mathrm{F}$, Bugalho $\mathrm{MJ}$, Matos $\mathrm{P}$, et al. $\mathrm{TNF} \alpha$-mediated activation of NF-KB downregulates sodiumiodide symporter expression in thyroid cells. PLoS One. 2020;15:e0228794. 


\section{PMid:32049985}

18. Kogai T, Taki K, Brent GA. Enhancement of sodium/iodide symporter expression in thyroid and breast cancer. Endocr Relat Cancer. 2206;13:797-826

PMid: 16954431

19. Smith VE, Read ML, Turnell AS, Watkins RJ, Watkinson JC, Lewy GD, et al. A novel mechanism of sodium iodide symporter repression in differentiated thyroid cancer. J Cell Sci. 2009;122(Pt 18):3393-402.

PMid:19706688

20. Ahad F, Ganie SA. lodine, lodine metabolism and iodine deficiency disorders revisited. Indian J Endocrinol Metab. 2010;14:13-7.

PMid:21448409

21. Elliyanti A, Rusnita D, Afriani N, Susanto YD, Susilo VY, Setiyowati $\mathrm{S}$, et al. Analysis natrium iodide symporter expression in breast cancer subtypes for radioiodine therapy response. Nucl Med Mol Imaging. 2020;54(1):35-42.

PMid:32206129

22. Darrouzet E, Lindenthal S, Marcellin D, Pellequer JL, Pourcher T. The sodium/iodide symporter: State of art of its molecular characterization. Biochim Biophys Acta. 2014;1838(Pt 1):244-53.

PMid:23988430

23. Fan YX, Liang ZX, Liu QZ, Xiao H, Li KB, Wu JZ. Cell penetrating peptide of sodium-iodide symporter effect on the I-131 radiotherapy on thyroid cancer. Exp Ther Med. 2017;13(3):989-94.

PMid:28450931

24. Son SH, rakash Gangadaran P, Ahn BC. A novel strategy of transferring NIS protein to cells using extracellular vesicles leads to increase in iodine uptake and cytotoxicity. Int J Nanomed. 2019;14:1779-87.

PMid:30880979

25. Kakudo K, Bychkov A, Baii Y, Li Y, Liu Z, Jung CK. The new $4^{\text {th }}$ edition world health organization classification for thyroid tumors, Asian perspectives. Pathol Int. 2018;68(12):641-64.

PMid:30537125

26. Wolff AC. Hammond ME, Hicks DG, Dowsett M, McShane LM, Allison $\mathrm{KH}$, et al. Recommendations for human epidermal growth factor receptor 2 testing in breast cancer: American society of clinical oncology/college of American pathologists clinical practice guideline update. J Clin Oncol 2013;31(31):3397-4013. PMid:24101045

27. Elledge RM, Green S, Pugh R, Allre DG, Clark GM, Hill J, et al. Estrogen receptor (ER) and progesterone receptor $(\mathrm{PgR})$, by ligand-binding assay compared with ER, PgR and pS2, by immuno-histochemistry in predicting response to tamoxifen in metastatic breast cancer: A Southwest oncology group study. Int J Cancer. 2000;89(2):111-7.

PMid: 10754487

28. Castro MR, Bergert ER, Beito TG, Roche PC, Ziesmer SC, Jhiang SM, et al. Monoclonal antibodies against the human sodium iodide symporter: Utility for immunocytochemistry of thyroid cancer. J Endocrinol. 1999;163(3):495-504.

PMid:10588823

29. Peyrottes I, Navarro V, Ondo-Mendez A, Marcellin D, Bellanger L, Marsault R, et al. Immunoanalysis indicates that the sodium iodide symporter is not overexpressed in intracellular compartments in thyroid and breast cancers. Eur J Endocrinol. 2009;160(2):215-25.

PMid:19029227

30. Castro MR, Bergert ER, Goellner JR, Hay ID, Morris JC. Immunohistochemical analysis of sodium iodide symporter expression in metastatic differentiated thyroid cancer:
Correlation with radioiodine uptake. J Clin Endocrinol Metab. 2001;86(11):5627-32.

PMid: 11701745

31. Tavares C, Coelho MJ, Eloy C, Melo M, da Rocha AG, Pestana A, et al. NIS expression in thyroid tumors, relation with prognosis clinicopathological and molecular features. Endocr Connect. 2018;7(1):78-90.

PMid:29298843

32. Caillou B, Troalen F, Baudin E, Talbot M, Filetti S, Schlumberger $\mathrm{M}$, et al. Na+/l- symporter distribution in human thyroid tissues: An immunohistochemical study. J Clin Endocrinol Metab. 1998;83(11):4102-6.

PMid:9814499

33. Lazar V, Bidart JM, Caillou B, Mahé C, Lacroix L, Filetti S, et al. Expression of the $\mathrm{Na}+/ /$ - symporter gene in human thyroid tumors: A comparison study with other thyroid-specific genes. J Clin Endocrinol Metab. 1999;84(9):3228-34.

PMid:10487692

34. D’Agostino M, Sponziello M, Puppin C, Celano M, Maggisano V, Baldan F, et al. Different expression of TSH receptor and NIS genes in thyroid cancer: Role of epigenetics. $\mathrm{J}$ Mol Endocrinol 2014;52(2):121-31.

PMid:24353283

35. Liu J, Liu Y, Lin Y, Liang J. Radioactive iodine-refractory differentiated thyroid cancer and redifferentiation therapy. Endocrinol Metab. 2019;34(3):215-25.

PMid:31565873

36. De La ViejaA, Dohan O, Levy O, Carrasco N. Molecular analysis of the sodium/iodide symporter: Impact on thyroid and extrathyroid pathophysiology. Physiol Rev. 2000;80(3):1083-105.

PMid:10893432

37. Jhiang SM, Cho JY, Ryu KY, De Young BR, Smanik PA McGaughy VR, et al. An immunohistochemical study of $\mathrm{Na}^{+} / l^{-}$ symporter in human thyroid tissues and salivary gland tissues. Endocrinology. 1998;139(10):4416-9.

PMid:9751526

38. Liu Z, Xing M. Induction of sodium/iodide symporter (NIS) expression and radioiodine uptake in non-thyroid cancer cells. PLoS One. 2012;7(2):e31729.

PMid:22359623

39. De Morais RM, Sobrinho AB, de Souza Silva CM, de Oliveira JR, da Silva IC, de Toledo Nóbrega O. The role of the NIS (SLC5A5) gene in papillary thyroid cancer: A systematic review. Int J Endocr. 2018;2018:9128754.

PMid:30595693

40. Elliyanti A, Susilo VY, Setiyowati S, Ramli M, Masjhur JS, Achmad TH. Uptake and cytotoxicity characterization of radioiodine in MCF-7 and SKBR3 breast cancer cell lines. Atom Indones. 2016;42(3):145-9.

41. Elliyanti A, Putra AE, Sribudiani Y, Noormartany N, Masjhur JS, Achmad $\mathrm{TH}$, et al. Epidermal growth factor and adenosine triphosphate induce natrium iodide symporter expression in breast cancer cell lines. Open Access Maced J Med Sci. 2019;7(13):2088-92.

PMid:31456831

42. Baskar R, Dai J, Wenlong N, Yeo R, Yeoh KW. Biological response of cancer cells to radiation treatment. Front $\mathrm{Mol}$ Biosci. 2014;1:1-9.

PMid:25988165

43. Morari EC, Marcello MA, Guilhen AC, Cunha LL, Latuff $P$ Soares FA, et al. Use of sodium iodide symporter expression in differentiated thyroid carcinomas. Clin Endocrinol. 2011;75(2):247-54

PMid:21521301 